\title{
Olumlu Sosyal Davranış Ĕ̆ilimi Ölçeğinin Psikometrik Özelliklerinin Kendini Belirleme Kuramı Bağlamında İncelenmesi
}

\section{Dr. Öğretim Üyesi Vezir Aktaş ${ }^{1}$ Doç. Dr. Yeliz Kındap Tepe ${ }^{2 *}$}

Geliș tarihi: 04.01.2020

Kabul tarihi: 13.02.2020

\section{At tf bilgisi:}

IBAD Sosyal Bilimler Dergisi

Sayı: $7 \quad$ Sayfa: $154-166$

Yıl: 2020 Dönem: Yaz

This article was checked by Turnitin. Similarity Index $24 \%$

Bu makalede araştırma ve yayın etiğine uyulmuştur.

${ }^{1}$ Jönköping Üniversitesi, İsveç, vezir.aktas@ju.se,

\section{ORCID ID 0000-0002-8475-1877}

219 Mayıs Üniversitesi, Türkiye, yelizkindap@gmail.com,

ORCID ID 0000-0003-0963-810X

\footnotetext{
* Sorumlu yazar
}

öz

Toplumsal yaşamın önemli bir yönünü oluşturan olumlu sosyal davranışlar, toplumun düzgün ișleyiși için kritik bir öneme sahiptir. Bu tur davranıșlar hemen hemen her toplumda takdir ve teşvik edilmektedir. Olumlu sosyal davranışlar konusunda son yıllarda yapılan çalışmalarda, olumlu sosyal davranışın çok boyutlu ve davranışın altında yatan motivasyona vurgu yapılarak, Kendini Belirleme Kuramı (KBK) çerçevesinde ele alındığında, olumlu sosyal davranışın altında yatan motivasyon içsel veya dışsal olabileceği öne sürülmektedir. Yapılan bu çalışmada Carlo ve Randall (2002) tarafindan geliştirilen ve altı farklı türde olumlu sosyal davranıșları ölçen Olumlu Sosyal Davranıș Eğilimi Ölçeği'nin psikometrik yapısı KBK temelinde incelenmiştir. Ölçek maddelerinin içsel ve dışsal motivasyon olarak ayrışıp ayrışmadığını belirlemek amacıyla yapılan analizler sonucunda, ölçeğin içsel motivasyon ve dişsal motivasyon ayırımı temelinde iki boyutlu olarak da kullanılabileceği görülmüştür. Ölçeğin içsel ve dışsal motivasyon alt boyutlarının güvenirliğinin yeterli düzeyde olduğu görülmüştür. Bununla birlikte, Carlo ve Randall'ın sınıflaması göz önüne alındığında, ölçeğin özellikle özgecilik alt boyutunun Türk kültürü bağlamında yeniden kavramsallaştırılmasına ihtiyaç duyulduğu belirlenmiş ve tüm sonuçlar KBK bağlamında tartışılmıştır.

Anahtar Kelimeler: İçsel Motivasyon, Dışsal Motivasyon, Kendini Belirleme Kuramı, Olumlu Sosyal Davranış 


\title{
Examination of Psychometric Properties of the Prosocial Tendencies Measure in the Context of Self-Determination Theory
}

\author{
Assist. Prof. Dr. Vezir Aktaş ${ }^{1}$ \\ Assoc. Prof. Dr. Yeliz Kindap Tepe ${ }^{2 *}$
}

First received: 04.01.2020

Accepted: 13.02.2020

Citation:

IBAD Journal of Social Sciences

Issue: 7 Pages: 154-166

Year: 2020 Session: Summer

This article was checked by Turnitin. Similarity Index $24 \%$

${ }^{1}$ Jönköping University, Sweden, vezir.aktas@ju.se,

ORCID ID 0000-0002-8475-1877

219 Mayss University, Turkey, yelizkindap@gmail.com,

ORCID ID 0000-0003-0963-810X

* Corresponding Author

\begin{abstract}
Prosocial behaviours, which constitute an important aspect of social life, are essential for the proper functioning of society. These kinds of behaviors are appreciated and encouraged in almost every society. Recent research on prosocial behaviour has started to emphasize the multidimensional nature and underlying motivations of prosocial behaviour. Within the framework of Self- Determination Theory (SDT) suggests that the motivation behind engaging in prosocial behaviour is intrinsic or extrinsic. In this study, the psychometric structure of The Prosocial Tendencies Measure, which was developed by Carlo and Randall (2002) and distinguishes between six different types of prosocial behaviours, was examined based on SDT. Analyses to determine whether the items of this scale can be classified as intrinsic and extrinsic motivational factors showed that the scale can be used in two dimensions as intrinsic-extrinsic motivations. We also found that these two factors demonstrated good internal consistency. However, when Carlo and Randall's (2002) classification is taken into consideration, it seems that, especially, the altruism sub-dimension needs to be re-conceptualized in the Turkish cultural context. The obtained results were discussed in the framework of Self Determination Theory.
\end{abstract}

Keywords: Intrinsic Motivation, Extrinsic Motivation, Self-Determination Theory, Prosocial Behaviour 


\section{GíRIŞ}

Toplumsal yaşamın önemli bir yönü olan Olumlu Sosyal Davranışlar (OSD-prosocial behaviors), toplumun düzgün işleyişi için kritik bir öneme sahiptir. Hemen hemen her toplum bu tür davranışları takdir ve teşvik etmektedir. Diğer bir ifadeyle, sosyalleşme surecinde bireylerin olumlu sosyal davranışlar geliştirmesi, buna karşın, örneğin, saldırganlık eğilimlerini denetlemeleri beklenmektedir. Genel anlamıyla başkalarına fayda sağlama amacı güden gönüllü davranışlar olarak tanımlanan (Eisenberg, 1986; Eisenberg ve Fabes, 1998; Weinstein ve Ryan, 2010) olumlu sosyal davranışlar, farklı bağlamlarda ortaya çıkabilir ve insanlar çeşitli nedenlerden dolayı başkalarına yardım etme davranışında bulunabilirler. Dolayısıyla, olumlu sosyal davranışların altında yatan motivasyonları anlamanın bu davranışı teşvik etmede önemli olduğu düşünülmektedir.

Alan yazınında olumlu sosyal davranışın empati ve başkalarının bakış açısına duyarlık ile bir arada ortaya çıktı̆̆ ifade edilmektedir (bkz., Eisenberg ve Fabes, 1998). Diğer kişinin duygularını hissetme olarak tanımlanan empati farklı duygusal tepkilerin ortaya çıkmasına yol açabilmektedir. Bu duygusal tepkilerden biri olan sempati, bir başkasının yararı amacıyla yardım etme olarak tanımlanmaktadır. Bir diğer duygusal tepki olan kişisel sıkıntı ise bir başkasının yardım istemesinin yarattığı olumsuz duygulanmaya işaret etmektedir. Empati ve sempati duygusu genellikle diğeri odaklı olumlu sosyal davranışta bulunmayı kolaylaştııırken, kişisel sıkıntı duygusu yardım isteyen karşısında sıkıntıdan kurtulmaya dönük benmerkezci, bencil temelli yardım etmeye yol açmaktadır (bkz., Eisenberg ve Fabes, 1998; Eisenberg, Wentzel ve Harris, 1998). Kişiler arası duyarlığın bilişsel boyutu olarak ele alınan başkalarının bakış açısına duyarlık ise, kendini diğer kişinin yerine koyarak onun düşüncelerini anlamaya çalışma şeklinde tanımlanmakta ve olumlu sosyal davranışla pozitif yönde ilişkili olduğu belirtilmektedir (bkz., Eisenberg ve Fabes, 1998; Eisenberg ve ark., 1998).

Olumlu sosyal davranışlar konusunda son yıllarda yapılan çalışmalarda, olumlu sosyal davranışın çok boyutlu yapısına (Carlo ve Randall, 2001; 2002) ve davranışın altında yatan motivasyona vurgu yapıldığı (Roth, 2008; Roth, Kanat-Maymon ve Bibi, 2011) dikkat çekmektedir. Örneğin, Tisak ve arkadaşları (Jackson ve Tisak, 2001; Tisak ve Ford, 1986) yardım etme, paylaşma vb. davranışların çocuklar tarafindan farklı şekillerde değerlendirildiğini ve kişilerarası ilişkilerde farklı işlevleri olduğunu ifade ederken, Carlo ve Randall (2002) ise ergenlerin psikososyal davranış eğilimlerini değerlendirmeleri sonucunda farklı türlerde olumlu sosyal davranış çeşitlerini tanımlayarak, Olumlu Sosyal Davranış Eğilimi Ölçeği'ni geliştirmiştir (Carlo ve Randall, 2002). Olumlu sosyal davranışların çok boyutluluğunu değerlendirmede yaygın olarak kullanılan ve 23 maddeden oluşan ölçek altı farklı olumlu sosyal davranış türünü ayırt etmektedir. Bunlar: Özgeci (temelde başkalarına yardım etme güdüsüyle içselleştirilmiş normlardan oluşan yardım etme davranışı), itaatkar (bir istek ya da rica olduğunda yapılan yardım), duygusal (duygusal uyarıcıların olduğu durumlarda yapılan yardım), acil (bir kriz durumunda yapılan yardım), kamusal (diğerlerinin önünde yapılan ve özünde saygı kazanma, onay alma gibi güdülerle yapılan yardım) ve gizli (yardım edenin kimliğinin belli olmadığı durumlarda yapılan yardım) olumlu sosyal davranışlar, şeklindedir. Carlo ve Randall (2001) farklı bağlamlardaki olumlu sosyal davranışları anlayabilmek/ölçebilmek için belirtilen sınıflamanın yararlı olduğunu ve bireylerin farklı motivasyonlarla olumlu sosyal davranışlar sergileyebildiklerini öne sürmektedirler. Örneğin dişsal faktörlerin kamusal olumlu sosyal davranış eğiliminde daha fazla rol oynaması beklenirken, içsel faktörlerin (self-motivated) özgeci ya da gizli olumlu sosyal davranış eğiliminde daha fazla rol oynaması beklenir (Carlo ve Randall, 2002).

Alan yazınında sosyal davranışların altında yatan mekanizmaları açıklamak için pek çok kuramsal yaklaşım öne sürülmektedir. Son yıllarda öne çıkan bu kuramsal yaklaşımlardan biri Deci ve Ryan (1985, 2000) tarafindan geliştirilen Kendini Belirleme Kuramıdır (Self Determination Theory). Genel olarak, motivasyon, gelişim ve psikolojik sağlığa odaklanan kuram, sosyal ve kültürel faktörlerin insanların performans ve psikolojik sağliklarının yanı sıra, irade ve inisiyatif algılarını (ya da davranışı kendisinin belirlemesi) nasıl geliştirdiğini veya zayıflattığını ele almaktadır. 


\section{Kendini Belirleme Kuramı (KBK)}

Altı alt kuramdan oluşan bir meta-kuram olarak Kendini Belirleme Kuramı (Deci ve Ryan, 1985, 2000; 2008b; Ryan, 2009), özellikle son yıllarda farklı motivasyon türlerinin sonuçları, kişilik gelişimi ve psikolojik sağlık (well-being) konularında yapılan çalışmalarda yaygın olarak kullanılmaktadır. Kurama göre davranışın altında yatan motivasyon iç ya da dış kaynaklı olabilir (Deci ve Ryan, 1985). İçsel motivasyon (intrinsic motivation), kişinin bir davranışı, sağladığı tatmin duygusundan dolayı gerçekleștirmesi olarak tanımlanmaktadır. Yani, bireyin davranışları maddi ödüller ya da dıș zorlamalardan bağımsız gönüllü, içten gelen davranışlardır. Anılan bu davranışlar zevk alındığı, değer verildiği, önemli bulunduğu için gerçekleştirilmektedir. İçsel motivasyon oldukça özerktir ve kendini belirlemenin prototipik durumunu temsil etmektedir. Öte yandan, dişsal motivasyon (extrinsic motivation), bir eylem ya da davranışın belirli bir sonucu elde etmek için gerçekleştirilmesi olarak tanımlanmaktadır (Ryan ve Deci, 2000a, 2000b). Birey, ödül almak veya cezadan kaçınmak gibi belirli sonuçlara yol açan davranışlarda bulunur. Kurama göre, dışsal motivasyonlu davranışlar özerklik derecesi açısından büyük farkl11ıklar gösterebilmektedirler. Buna göre, içselleştirme (internalization) ve bütünleştirme (integration) süreçleri sayesinde, dışsal motivasyonlu davranışlar, tıpkı içsel motivasyonlu davranışlarda olduğu gibi, özerkliğe sahip olabilmektedirler. İçselleştirme bireyin bir değeri kabul etmesi ve içselleştirmesine işaret ederken, bütünleştirme ise söz konusu düzenlemenin bireyin benliğinin bir parçası olarak dönüştürülmesine işaret etmektedir. Diğer bir ifadeyle, davranış dışsal olarak motive olsa bile (örneğin dişsal zorlamalar), kişi içselleştirme ve bütünleştirme süreçlerinden geçtikten sonra yüksek düzeyde özerklik yaşayabilir ve sözkonusu davranışta bulunmak üzere güdülenebilir. KBK'a göre davranışı düzenlemenin ya da içselleştirilmenin ne derece özerk bir şekilde yapıldığına bağlı olarak dışsal bir motivasyonla harekete geçen davranıştaki iradelilik hissi farklılaşabilmektedir (Ryan ve Connell, 1989; Vallerand, 1997). Diğer bir ifadeyle, kendini düzenleme dişsaldan içsele doğru özerklik düzeyine göre bir süreklilik göstermektedir. Buna göre, her biri farklı özerklik derecelerini yansıtan dört tür dışsal motivasyon düzenlemesi bulunmaktadır. Bunlar, dışsal düzenleme (external regulation), içe yansıtılmış düzenleme (introjected regulation), özdeşimle düzenleme (identified regulation) ve bütünleşmiş düzenlemedir (integrated regulation). İlk iki düzenlemede davranışın nedeni kişinin dışından (kontrollü motivasyon), son iki düzenlemede ise kişinin içinden gelmekte (özerk motivasyon) ve buna bağlı olarak kişinin kendini düzenleme biçimleri farklılaşmaktadır. Dolayısıyla ilk iki düzenlemede davranışın nedenleri dışsal kaynaklı alģlandığından daha az özerklik hissi yaşanırken; son iki düzenlemede davranışın nedenleri içsel olarak algılandığı için davranışta daha fazla özerklik ya da iradelilik hissi yaşanmaktadır (Ryan ve Deci, 2000a, 2000b). Bu kavramsallaştırmadan dolay1, KBK'da son yıllarda içsel ve dişsal motivasyon kavramları yerine, "özerk motivasyon" (içsel motivasyon ile dışsal motivasyonun özdeşimle düzenleme ve bütünleşmiş düzenleme türlerini içerir) ve "kontrollü motivasyon" (dışsal motivasyonun içe yansitılmış düzenleme ve dişsal düzenleme türlerini içerir) kavramları kullanılmaya başlanmıştır (Deci ve Ryan, 2008a; 2008b).

Kendini Belirleme Kuramı'nda (KBK), ayrıca, yaşamın ilk yıllarından itibaren birey için üç temel psikolojik ihtiyaçtan söz edilmektedir. Bunlar; özerklik (autonomy), ilişkisellik (relatedness) ve yeterlik (competence) ihtiyaçlarıdır (Deci ve Ryan, 2000; Ryan ve Deci, 2000a; Ryan, Deci ve Grolnick, 1995). Özerklik ya da kendini belirleme, kişinin benlik tarafından onaylanan ve benlikle bütünlük içinde olan davranışlarını sergileme ihtiyacıdır ve kişinin davranışları başlatma, sürdürme ve son vermeyle ilgili tercih, onay ve irade hissini deneyimlemesi olarak kavramsallaştırılmaktadır (Deci ve Ryan, 2000). İlişkisellik ihtiyacı, diğerlerinden algılanan sıcaklık ve bakımın (ilginin) bir sonucu olarak ortaya çıkan genel bir ait olma duygusu olarak tanımlanmaktadır (Baumeister ve Leary, 1995; Deci ve Ryan, 1991). Yeterlik ise, sosyal ve fiziksel dünyayla etkileşiminde bireyin etkili olduğu duygusunu hissetmesi olarak ele alınmaktadır (Deci ve Ryan, 1991; Deci, Vallerand, Pelletier ve Ryan, 1991). KBK'da temel psikolojik ihtiyaçların doyurulmasının davranışın altında yatan ve davranışı yönlendiren motivasyonu arttırdığ (Deci ve Ryan, 2000), sözkonusu temel psikolojik ihtiyaçların evrensel olduğu (Deci ve Ryan, 1985, 2000; Ryan ve Deci, 2000a, 2008) ve bunların sosyal çevre tarafindan desteklenmesinin sosyal gelişim ve bireyin psikolojik iyi olma haline katkıda bulunduğu öne sürülmektedir (Deci ve Ryan, 2014; Ryan, 1995; Ryan, Deci ve Grolnick, 1995). Buna göre, üç temel psikolojik gereksinimin karşılanması içsel güdülenmeyi artırmakta, ancak içsel güdülenmenin sürdürülmesi sosyal çevreye bağlı olmaktadır. 
Temel psikolojik ihtiyaçlarının sosyal çevre (ebeveyn, öğretmen, patron vs) tarafından doyurulmasının kişinin kendini özerk olarak düzenlemesini ya da sosyal değerleri içselleştirilmesini kolaylaştırabildiği (Deci ve Ryan, 2008a; Ryan ve Deci, 2000), temel psikolojik ihtiyaçların sosyal çevre tarafindan doyurulmasında yaşanan sıkıntıların ise tam tersi bir etkisinin olduğu, çeşitli psikolojik problemlere yol açabildiği (Deci ve Ryan, 2000; 2014) ifade edilmektedir.

Son yıllarda KBK çerçevesinde yapılan bazı çalışmalar bireyin temel psikolojik ihtiyaçlarının yakın çevre tarafindan giderilmesi ile olumlu sosyal davranışlar arasında pozitif bir ilişkinin olduğunu (Gagné, 2003; Weinstein ve Ryan, 2010) göstermiştir. Buna göre, özerkliği destekleyici ebeveynlik ergenin özerk motivasyonla hareket etmesine ve bu yolla, ergenin daha sıklıkla olumlu sosyal davranışlar sergilemesine yol açabilmektedir (Assor, Roth ve Deci; 2004; Roth, 2008). Diğer bir ifadeyle, temel psikolojik ihtiyaçları tatmin edilen bir bireyin daha fazla olumlu sosyal davranış sergileme eğiliminde olacağı ileri sürülmektedir (Ryan ve Connell, 1989; Ryan ve Deci 2000a).

Olumlu sosyal davranışlar bencilden (egoistic) özgeciye (alturistic), dışsaldan içsele farklı süreçler tarafindan motive olabilmektedir (Ryan ve Connell, 1989). Kendini Belirleme Kuramı bağlamında değerlendirildiğinde, olumlu sosyal davranışın altında yatan motivasyonun içsel veya dışsal olabileceği (Ryan ve Deci, 2000a); kendiliğinden özerk bir motivasyonla yapılan davranışların "diğeri” yönelimli OSD, bir yarar elde etme amacına yönelik olarak yapılan davranışların ise "kendi" yönelimli OSD olduğu öne sürülmektedir (Roth, 2008). Nitekim, Ryan ve Connell (1989), olumlu sosyal davranışlar sözkonusu olduğunda, kendi yönelimli (self-focus) OSD’nin ise dışsal motivasyonla, diğeri yönelimli OSD ise daha ziyade özerklik (autonomous) ve içsel motivasyonla ilişkili olduğunu ifade etmişlerdir. Yapılan çalışmalarda, olumlu sosyal davranışın bir dereceye kadar içsel motivasyonla yönlendirildiği gösterilmiş̧ir (Hepach, Vaish ve Tomasello, 2013; Warneken ve Tomasello, 2008). Gagné (2003) ise yaptığı çalışmadan hareketle olumlu sosyal davranışlarının altında yatan motivasyonun içsel olma olasılığının daha yüksek olduğu ifade etmiştir. Ayrıca içsel olarak (özerk) motive olan olumlu sosyal davranışın, davranışın kalıcılığını, performansını ve üretkenliğini daha güçlü bir şekilde yordadığı bulunmuştur (Grant, 2008; Grant ve Berg, 2010). Öte yandan, Carlo ve arkadaşlarının (Carlo ve Randall, 2001; 2002; Carlo, Hausmann, Christiansen ve Randall, 2003) sinıflamasındaki olumlu sosyal davranışların altında yatan motivasyonlar Kendini Belirleme Kuramı temelinde değerlendirildiğinde, tüm boyutlarda özerklik hissinin bulunduğu ancak davranışların içsel ve dışsal nedenle harekete geçmesi açısından başkalaştıkları söylenebilir. Örneğin, Carlo ve arkadaşlarının (2002; 2003) tanımlamasından hareketle, kamusal olumlu sosyal davranışın dişsal (kontrollü) motivasyonla, gizli olumlu sosyal davranışın ise daha ziyade içsel (özerk) motivasyonla harekete geçen davranışlar olabileceği düşünülmektedir. Nitekim, yapılan çalışmalarda kamusal olumlu sosyal davranışın sempati ve başkalarının bakış açısına duyarlık ile negatif ilişki gösterdiği; duygusal ve itaatkâr olumlu sosyal davranışların ise olumlu sosyal davranışla ilgili ahlaki muhakeme, sempati ve başkalarının bakış açısına duyarlık ile pozitif ilişkili olduğu bulunmuştur (bkz., Carlo ve Randall, 2002; Carlo ve ark., 2003).

Buraya kadar özetlenen bilgilerden hareketle yapılan bu çalışmada Carlo ve Randall (2002) tarafından geliştirilen ve altı farklı türde olumlu sosyal davranışa vurgu yapan Olumlu Sosyal Davranış Eğilimi Ölçeği'nin psikometrik yapısı KBK temelinde değerlendirmiştir. Alan yazınındaki çeşitli araştırmalara (Gagné, 2003; Grant, 2008) ve KBK'nin temel varsayımlarına dayanılarak (Deci ve Ryan, 2000), olumlu sosyal davranışların ağırlıklı olarak içsel motivasyon tarafından yönlendirildiği düşünülmektedir (Kindap-Tepe ve Aktas, 2019). Dolayısıyla, bu çalışmanın amacı Olumlu Sosyal Davranış Eğilimi Ölçeği'nin Türkçe versiyonunu KBK temelinde içsel (özerk) /dışsal (kontrollü) motivasyon bağlamına uyarlamak ve doğrulamaktır. Bilindiği kadarıyla söz konusu ölçeğin faktör yapısının kendini belirleme kuramı çerçevesinde ele alındığı ilk çalışma olması araştırmaya önem kazandırmaktadır. Yapılan çalışmanın hem söz konusu ölçeğin kullanılabilirlik alanının genişlemesine hem de KBK kavramsal çerçevesinin olumlu sosyal davranışlara uyarlanmasına katkı sunması beklenmektedir. 


\section{YÖNTEM}

\section{Örneklem}

Araştırma örneklemini farklı bölümlerde okuyan lisans öğrencileri oluşmaktadır. Katılımcılara amaçlı örneklem seçme yöntemlerinden kolay ulaşılabilir durum örneklemesi yöntemiyle ulaşılarak, toplam 389 kişiden (200 kadın ve 189 erkek) veri toplanmıştır. Yaşları 19-31 arasında değişen $($ Ort. $=21.91, S=$ 1.72) katılımcıların üniversitede bulunma yılının dağılımı şöyledir: 95 kişi üniversitede birinci yılında, 125 kişi ikinci yılında ve 169 kişi üçüncü yılındadır.

\section{Veri Toplama Araçları}

Olumlu Sosyal Davranış Eğilimi Ölçeği (Prosocial Tendencies Measure). Carlo ve Randall (2002) tarafından ilk olarak üniversite öğrencileri için geliştirilen ölçek toplam 23 maddeden oluşmaktadır. Her bir madde 5 dereceli ölçek (1- beni hiç tanımlamıyor; 5- beni çok iyi tanımlıyor) üzerinden değerlendirilmektedir. Bu ölçme aracı 6 alt ölçekten oluşmaktadır. Ergenlik döneminin başlarında ve ortasında olan gençlerle yapılan çalışmadan elde edilen Cronbach Alfa katsayıları her iki yaş grubunda sırasıyla kamusal alt boyutu için .76-.86, duygusal alt boyutu için .86-.82, özgeci alt boyutu için .59.80 , itaatkâr alt boyutu için, .80-.75, gizli alt boyutu için .76-.84 ve acil durumlardaki olumlu sosyal davranış alt boyutu için .71 ve .75 olarak bulunmuştur. Buna ilaveten alt ölçeklerin 2 haftalık testtekrar test güvenirlik katsayıları .54 ile .82 arasında değişmektedir (Carlo ve ark., 2003). Kumru ve ark., (2004) tarafından Türk örnekleminde yapılan çalışmada ölçeğin 23-maddelik formu ve 5 alt boyutu kullanılarak Cronbach Alfa iç tutarlılık katsayılarının alt ölçekler için .52 ile 68 arasında değiştiği ifade edilmiştir. Bu araştırma kapsamında ölçeğin psikometrik özellikleriyle ilgili bilgilere bulgular bölümünde yer verilmiştir.

Özerkliği Destekleme Ölçeği (Autonomy Support). Gençlerin anne ve babalarından algıladığı özerklik desteği düzeyini belirlemek amacıyla Soenens ve arkadaşları (2007) tarafından geliştirilmiştir. Toplam 7 madde oluşan ve 5'li Likert üzerinden değerlendirilen ölçeğin (1- hiç katılmıyorum, 5- çok katılıyorum) Cronbach Alfa iç tutarlık katsayıs1 .79 olarak ifade edilmiştir (Soenens ve ark., 2007). Türkçeye uyarlaması Kındap (2011) tarafindan yapılan ölçeğin Cronbach Alfa iç tutarlık katsayısının anne bildirimi için .81 , baba bildirimi için .82 olarak bulunmuştur. Bu araştırma kapsamında ölçeğin Cronbach Alfa iç tutarlık katsayısı gencin anne bildirimi için .80; baba bildirimi için .88'dir.

Psikolojik Kontrol Ölçeği (Psychological Control Questionnaire). Ebeveynlerin ergen üzerinde uyguladığı psikolojik kontrolü ölçmek amacıyla Barber (1996) tarafindan geliştirilen Psikolojik Kontrol Ölçeği kullanılmıştır. Toplam 8 madde ile ölçülen annenin uyguladı̆̆ 1 psikolojik kontrol ("Annem eğer onu utandıracak bir şey yaparsam, beni görmezden gelmeye çalıştığı olur"; 1- kesinlikle katılmıyorum, 5- kesinlikle katılıyorum) beş dereceli Likert tipi bir ölçektir. Orijinal ölçeğin Cronbach Alfa iç tutarlık katsayısının anne için .72 ile .85; baba için .74 ile .86 arasında değiştiği bulunmuştur (Barber, 1996). Ölçeğin Türkçe'ye uyarlama çalışması Sayıl ve Kındap (2010) tarafindan yapılmış olup anne için .77 baba için .79 olarak bulunmuştur. Bu araştırmada ise Cronbach Alfa iç tutarlık katsayısı anne formu için .74; baba formu için .80 olarak bulunmuştur.

Psikolojik İhtiyaçların Tatmini Ölçeği (Basic Psychological Need Satisfaction Scale). Toplam 21 maddeden oluşan ölçek temel psikolojik ihtiyaçlarının ne derece doyurulduğunu belirlemek amacıyla Deci ve Ryan (2000) ve Gagné (2003) tarafından geliştirilmiştir. Özerklik, yeterlik ve ilişkisellik alt boyutlarından oluşan ölçekte katılımcıların verdikleri tepkiler 5'li Likert üzerinden değerlendirilmektedir (1- hiç katılmıyorum, 5- çok katılıyorum). Türkçeye uyarlaması Şimşek ve Yalınçetin (2010) tarafindan yapılan ölçeğin Cronbach Alfa iç tutarlık katsayısı .82 olarak bulunmuştur. $\mathrm{Bu}$ araştırma örnekleminde ise ölçeğin Cronbach Alfa iç tutarlık katsayıs1 .71'dir.

\section{İşlem ve Etik}

Araştırma için gerekli izinler alınmış, ölçekler katılımcılara toplu uygulama şeklinde sınıf ortamında uygulanmıştır. Katılımcıya uygulamanın başında araştırma ile ilgili hem sözlü hem de yazılı (Onam Formu ile) bilgi verilmiştir. Katılımcılara araştırmanın adı ve amacı, bilgilerin gizliliği, kimlik 
bilgilerinin alınmayacağı ve ölçekleri doldurmanın yaklaşık ne kadar süreceği (20 ile 40 dakika) ile ölçeklerin ne şekilde doldurulması gerektiği hakkında bilgiler verilmiş, katılımın gönüllülük esasına dayalı olduğu belirtilmiştir.

\section{BULGULAR}

Olumlu Sosyal Davranış Eğilimi Ölçeğinin KBK bağlamındaki yapı geçerliliği belirlemek amacıyla ilk aşamada açımlayıcı faktör analizi (explanatory factor analysis) yapılarak, söz konusu ölçek maddelerinin faktör yapısı temel bileşenler analiziyle değerlendirilmiştir. Verinin analiz için uygunluğunu sınamak amacıyla Kaiser-Meyer-Olkin $(\mathrm{KMO})$ değeri hesaplanmış $(\mathrm{KMO}=.86)$ ve verinin faktör analizi için uygun olduğu görülmüştür. Yapılan temel bileşenler analizi sonucunda özdeğeri 1'den büyük olan beş faktör elde edilmiştir. Bu faktörlerin özdeğerleri 5.34, 3.66, 1.56, 1.10 ve 1.01 şeklinde saptanmıştır. Varimax rotasyonu kullanılarak maddeler iki faktöre zorlandığında ölçekte yer alan maddelerin iki istisna dışında içsel ve dışsal motivasyon olarak temsil edildiği görülmüştür. Ölçeğin madde faktör yükleri Tablo 1'de sunulmaktadır. İki faktörlü yapının toplam varyansın \%39.18'ini açıkladığı bulunmuştur. Analiz sonucunda dışsal motivasyon alt boyutunda yer alması beklenen 9. maddenin ("Bağışların artması için bağış yapanlara vergi indirimi uygulanması gerektiğine inanırım") içsel motivasyon alt boyutunda yer aldığı; içsel motivasyon alt boyutunda yer alması beklenen 16. maddenin ("Başkalarına en iyi yardımı oldukça duygusal ortamlarda yaparım.") dışsal motivasyon alt boyutunda yük aldığı belirlenmiş ve her iki maddenin analiz dışı bırakılmasına karar verilmiştir. Cronbach Alfa iç tutarlılık katsayısı ise içsel motivasyon alt boyutu için .86; dişsal motivasyon alt boyutu için .77 olarak hesaplanmıştır.

Tablo 1. Olumlu Sosyal Davranış Eğilimi Ölçeği Maddelerinin Faktör Yükleri

\begin{tabular}{|c|c|c|}
\hline Maddeler & $\begin{array}{c}\text { İçsel } \\
\text { Motivasyon }\end{array}$ & $\begin{array}{r}\text { Dişsal } \\
\text { Motivasy }\end{array}$ \\
\hline $\begin{array}{l}\text { Genellikle isimsiz bağışlar yaptığımda kendimi daha iyi hissederim. } \\
\text {-Gizli }\end{array}$ & .75 & -.14 \\
\hline İnsanlar benden yardım istedikleri zaman tereddüt etmem. -Itaatkâr & .73 & .03 \\
\hline $\begin{array}{l}\text { Ağır biçimde zarar görmüş insanlara yardım etme eğilimindeyim. - } \\
\text { Acil }\end{array}$ & .71 & .01 \\
\hline $\begin{array}{l}\text { Gerçekten zor durumda ya da ihtiyaç içinde olan insanlara yardım } \\
\text { etme eğilimindeyim. -Acil }\end{array}$ & .71 & .08 \\
\hline $\begin{array}{l}\text { Başkaları benden yardım istediğinde gecikmeden yardım ederim. - } \\
\text { Itaatkâr }\end{array}$ & .69 & .02 \\
\hline $\begin{array}{l}\text { İhtiyacı olan insanlar kim olduğumu bilmedikleri zaman onlara daha } \\
\text { çok yardım etme eğilimindeyim. -Gizli }\end{array}$ & .69 & -.03 \\
\hline Problemi olan birine yardım ettiğimde çok mutlu olurum. -Acil & 68 & -.01 \\
\hline $\begin{array}{l}\text { İnsanlara gerçekten hassas ve duygulu olduklarında özellikle yardım } \\
\text { ederim. -Duygusal }\end{array}$ & .60 & .09 \\
\hline $\begin{array}{l}\text { İnsanlara genellikle, kimin yardım ettiğini bilmediklerinde yardım } \\
\text { ederim. -Gizli }\end{array}$ & .58 & -.08 \\
\hline $\begin{array}{l}\text { Bence en iyi yardım, yapanın kim olduğunun bilinmediği yardımdır. } \\
\text {-Gizli }\end{array}$ & .55 & -.13 \\
\hline $\begin{array}{l}\text { Başkaları kötü bir durumda olduğu zaman benim için yardım etmek } \\
\text { kolaydır. -Duygusal }\end{array}$ & .45 & -.15 \\
\hline $\begin{array}{l}\text { Duygusal ortamlar bende muhtaçlara yardım etme isteği uyandırır. - } \\
\text { Duygusal }\end{array}$ & .44 & .31 \\
\hline $\begin{array}{l}\text { Para bağışı yaptığım zaman ismimin bilinmemesini tercih ederim. } \\
\text { Gizli }\end{array}$ & .43 & .34 \\
\hline 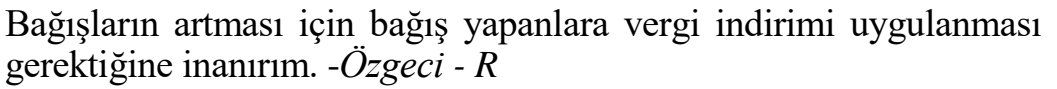 & .38 & .24 \\
\hline $\begin{array}{l}\text { Etrafta başkaları olduğu zaman, ihtiyacı olanlara yardım etmek } \\
\text { benim için daha kolaydır. -Kamusal }\end{array}$ & .01 & .72 \\
\hline Etraftan birileri görecekse başkalarına daha çok yardım ederim. - & -.17 & .70 \\
\hline
\end{tabular}




\section{Kamusal}

En çok etrafta başka birileri varken yardım ederim. -Kamusal

Birileri benim yaptıklarımı izlediğinde, başkalarına en iyi şekilde yardım ederim. -Kamusal

Hayır işlerine (gönüllü hizmetlere) ayırdığım zaman ve emek için daha fazla ödüllendirilmem gerektiğine inanırım. -Özgeci $-R$

Başkalarına yardım etmenin en iyi tarafi, sizin iyi biri olarak tanınmanızı sağlamasıdır. - Özgeci - $R$

Hayır işlerinde çalışmanın en iyi yanlarından biri özgeçmişime yazdığımda saygınlık kazandırmasıdır. - Özgeci $-R$

Yardım etmenin en iyi tarafi gelecekte karşıdakinden yardım alabilmektir. - Özgeci - $R$

Başkalarına en iyi yardımı oldukça duygusal ortamlarda yaparım. -

Duygusal

\section{Özdeğer}

Açıklanan Varyans

Alfa Katsayıs
.02

$-.14$

.00

$-.01$

.58

.07

$-.05$

.20

5.34

.41

3.66

23.25

15.93

.86
.57

.45

\section{Uyuşma (convergent) ve Ayrılık (discriminant) Geçerlikleri}

Uyuşma geçerliğini sınamak için araştırmada ölçeğin anne babadan algılanan psikolojik kontrol, özerk irade desteği, temel ihtiyaç tatmini arasındaki ilişkiler Pearson Korelasyon katsayısı hesaplanarak incelenmiştir. Tablo 2'den de görülebileceği gibi ölçeğin içsel motivasyon boyutunun beklendik şekilde anne ve babadan algılanan özerk irade desteğiyle pozitif yönde ilişkili olduğu; buna karşı anne babadan algılanan psikolojik kontrolle negatif yönde ilişkili olduğu görülmüştür. Ayrıca ölçeğin dişsal motivasyon alt boyutunun beklendik şekilde anne ve babadan algilanan özerk irade desteğiyle negatif yönde ilişkili olduğu; buna karşı anne babadan algılanan psikolojik kontrolle pozitif yönde ilişkili olduğu belirlenmiştir. Genel temel psikolojik ihtiyaçlarla pozitif yönde ilişkili olduğu görülmüştür. Olumlu Sosyal Davranış Eğilimi Ölçeği'nin içsel motivasyon alt boyutunun psikolojik ihtiyaçların tatmini ile pozitif yönde ilişkili olduğu; buna karşı ölçeğin dışsal motivasyon alt boyutuyla negatif yönde ilişkili olduğu ancak ilişsinin istatistiksel olarak anlamlı olmadığı belirlenmiştir.

Tablo 2. Olumlu Sosyal Davranış Eğilimi Ölçeğinin Araştırmada Ele Alınan Diğer Değişkenler ile İlişkisi

\begin{tabular}{lccccccc}
\hline Değişkenler & $\mathbf{1}$ & $\mathbf{2}$ & $\mathbf{3}$ & $\mathbf{4}$ & $\mathbf{5}$ & $\mathbf{6}$ & $\mathbf{7}$ \\
\hline 1. İşel Motivasyonlu OSD & - & & & & & & \\
2. Dişsal Motivasyonlu OSD & .01 & - & & & & & \\
3. Anne Özerk İradeyi Destekleme & $.23^{* * *}$ & $-.10^{*}$ & - & & & & \\
4. Baba Özerk İradeyi Destekleme & $.25^{* * *}$ & -.01 & $.41^{* * *}$ & - & & & \\
5. Anne Psikolojik Kontrol & $-.10^{*}$ & $.11^{*}$ & $-.32^{* * *}$ & $-.20^{* * *}$ & - & & \\
6. Baba Psikolojik Kontrol & $-.11^{*}$ & $.15^{* * *}$ & $-.18^{* * * *}$ & $-.39^{* * *}$ & $.45^{* * *}$ & - & \\
7. Temel İhtiyaç Tatmini & $.45^{* * *}$ & -.01 & $.42^{* * *}$ & $.46^{* * *}$ & $-.26^{* * *}$ & $-.24 * * *$ & - \\
\hline
\end{tabular}
Not. ${ }^{*} p<.05, * * p<.01, * * * p<.001$.

\section{BULGULAR}

Yapılan bu çalışmada Carlo ve Randall (2002) tarafindan geliştirilen ve farklı türlerde olumlu sosyal davranışlara vurgu yapan Olumlu Sosyal Davranış Eğilimi Ölçeği'nin psikometrik yapısı KBK temelinde incelenmiş ve elde edilen bulguların iki farklı sonuca işaret ettiği görülmüştür. Bunlardan birincisine göre, 23 maddeden oluşan Olumlu Sosyal Davranış Eğilimi Ölçeği maddelerinin içsel (özerk) ve dışsal (kontrollü) motivasyon olarak ayrışıp ayrışmadığını belirlemek amacıyla yapılan analizler sonucunda elde edilen bulgular, genel olarak, ölçeğin içsel motivasyon ve dışsal motivasyon ayırımı temelinde iki boyutlu olarak da kullanılabileceğine (olumlu sosyal davranış türleri göz önüne 
alınmaksızın) ve açıklanan toplam varyansın yeterli düzeyde olduğuna (\%39.18) işaret etmektedir. İç tutarlılık açısından bakıldığında ise boyutların güvenirliğinin yeterli düzeyde olduğu görülmüştür.

Araştırmadan elde edilen bulgular Carlo ve Randall (2002) tarafından tanımlanan altı değişik olumlu sosyal davranış türü açısından değerlendirildiğinde ise Olumlu Sosyal Davranış Eğilimi Ölçeği'nin alt boyutlarından olan ve ölçekte ters yönde puanlanması gereken özgeci (altruistic) ile kamusal (public) olumlu sosyal davranışların daha ziyade dışsal motivasyonla, gizli (anonymous), duygusal (emotional), itaatkâr (compliant) ve acil (dire) olumlu sosyal davranışların ise daha ziyade içsel motivasyonla güdülendikleri görülmüştür. Her iki değerlendirmede de olumlu sosyal davranış maddelerinin büyük bir çoğunluğunun içsel motivasyon boyutunda yer alması bu davranışların ağırlıklı olarak içsel motivasyon tarafindan yönlendirildiği yönündeki beklentilerle uyuşmaktadır (Gagné, 2003; Grant, 2008).

Kavramsal olarak, başkaları önünde yapılan ve özünde diğerlerinden onay ve saygı kazanma isteği tarafından güdülenen yardım etme davranışı olarak tanımlanan kamusal olumlu sosyal davranışların (Carlo ve Randall, 2002) yapılan analizlerde dışsal motivasyon boyutunda yer alması şaşırtıcı gelmemektedir. Beklentilerin aksine, bir istek ya da rica sözkonusu olduğunda yapılan yardım olarak kavramsallaştırılan itaatkâr olumlu sosyal davranışların dışsal motivasyon yerine içsel motivasyon boyutunda yer alması, anılan bu davranışların katılımcılar tarafından içselleştirildiğine işaret etmektedir. KBK'da özerklik derecesi açısından dışsal motivasyonlu davranışlar arasında farklılıklar bulunduğu; kendini düzenlemenin dışsaldan içsele doğru özerklik düzeyine göre bir süreklilik gösterdiği ve dolayısıyla da dışsal motivasyonlu davranışların, tıpkı içsel motivasyonlu davranışlarda olduğu gibi, özerkliğe sahip olabilecekleri ifade edilmiştir (Ryan ve Deci, 2000a, 2000b). Buna göre, dişsal düzenleme ve/veya içe yansıtılmış düzenleme süreçlerinin kamusal olumlu sosyal davranışlarda daha etkili olduğu, katılımcıların davranışın nedenlerine ilişkin daha az özerklik hissi yaşadıkları söylenebilir. Benzer şekilde, katılımcıların özdeşimle düzenleme ve/veya bütünleşmiş düzenleme süreçleri yoluyla itaatkâr olumlu sosyal davranışları içselleştirdikleri dolayısıyla daha fazla özerklik hissi yaşadıkları söylenebilir. Nitekim, yapılan çalışmalarda Türkiye'de ergenlik dönemindeki bireylerin en az kamusal, en fazla itaatkâr olumlu sosyal davranışlar gösterdikleri ifadede edilmiştir (Kumru, Carlo ve Edwards, 2004). Analizler kapsamında gizli (yardım edenin kimliğinin belli olmadığı durumlarda yapılan yardım), duygusal (duygusal uyarıcıların olduğu durumlarda yapılan yardım) ve acil (bir kriz durumunda yapılan yardım) olumlu sosyal davranış türlerinin de içsel motivasyonlu davranışlar boyutunda yere alması bu davranışların özdeşimle düzenleme ve bütünleşmiş düzenleme süreçleri yoluyla katılımcılar tarafından içselleştirildiğini düşündürtmektedir. Öte yandan, temelde başkalarına yardım etme güdüsüyle içselleştirilmiş normlardan oluşan, sempati duygusundan kaynaklanan ve başkalarının ihtiyaçlarını/iyiliğini önemseyen yardım etme davranışı olarak kavramsallaştırılan özgeci olumlu sosyal davranışların (Eisenberg ve Fabes, 1998), beklentilerin aksine, içsel motivasyon yerine dişsal motivasyon boyutunda yer alması söz konusu ölçek maddelerinin orijinal ölçekte ters puanlanması gereken maddeler olarak formüle edilmesiyle açılanabilir. Olası bir diğer açıklama ise orijinal özgeci olumlu sosyal davranışları ölçebilmek amacıyla kullanılan maddelerinin Türk kültürel bağlamında özgecilik kavramına karşılık gelmeyebileceğidir. Empati ve sempati duygusunun özgeci olumlu sosyal davranışlarla pozitif yönde ilişkili olduğu ve diğeri odaklı olumlu sosyal davranışta bulunmayı kolaylaştırdığı bilinmektedir (bkz., Eisenberg ve Fabes, 1998). Dolayısıyla, özgeci olumlu sosyal davranışların içsel motivasyonla harekete gecen davranış grubunda yer alması beklenir. Ancak, araştırma kapsamında elde edilen bulgular, mevcut haliyle özgeci olumlu sosyal davranış alt ölçek maddelerinin Türk kültürel bağlamında özgeciliği ölçmediğini düşündürtmektedir. Örneğin "Başkalarına yardım etmenin en iyi tarafi, sizin iyi biri olarak tanınmanızı sağlamasıdır." veya "Bağışların artması için bağı̧s yapanlara vergi indirimi uygulanması gerektiğine inanırım." şeklinde formüle edilen özgeci olumlu sosyal davranış maddelerinin, ters puanlanıyor olsalar bile, Türk kültürel bağlamında özgeciliğe karşıllık gelmediği söylenebilir.

Ölçüt geçerliği kapsamında elde edilen bulgular, içsel motivasyon boyutunun ebeveynlerden algılanan özerk irade desteğiyle pozitif yönde, anne babadan algılanan psikolojik kontrolle negatif yönde ilişkili olduğunu; dışsal motivasyon boyutunun ise anne ve babadan algılanan özerk irade desteğiyle negatif yönde, anne babadan algılanan psikolojik kontrolle pozitif yönde ilişkili olduğunu göstermiştir. Temel psikolojik ihtiyaçların tatmini açısından bakıldığında ise içsel motivasyon boyutunun psikolojik 
ihtiyaçların tatmini ile pozitif yönde ilişkili olduğu, dışsal motivasyon boyutu ile olan ilişkinin istatistiksel olarak anlamlı olmadığı belirlenmiştir. Alan yazınında, KBK temelinde, ebeveyn uygulamaları genellikle kontrol (davranışsal ve psikolojik kontrol) ve destek olarak iki boyutta ele alınmaktadır (Barber, Stolz ve Olsen, 2005; Bean, Barber ve Crane, 2006). Olumlu sosyal davranışlar alanında yapılan araştırmalar destekleyici ebeveynlik uygulamalarının olumlu sosyal davranışlar alanındaki özerk motivasyonuyla ilişkili olduğuna işaret etmektedir (Assor ve ark., 2004; Gagne 2003; Kındap, 2011; Roth, 2008; Ryan ve Connell, 1989). Benzer şekilde temel psikolojik ihtiyaçlarının sosyal çevre tarafindan tatmin edilmesinin kişinin kendini özerk olarak düzenlemesine katkıda bulunduğu ifade edilmektedir (Deci ve Ryan, 2008a; Ryan ve Deci, 2000a).

\section{Sonuç ve Öneriler}

Araştırmanın sonucunda elde edilen bulgular 23 maddeden oluşan Olumlu Sosyal Davranış Eğilimi Ölçeği maddelerinin, olumlu sosyal davranış türleri göz önüne alınmaksızın, KBK çerçevesinde içsel (özerk) ve dışsal (kontrollü) motivasyonlu davranışlar olarak ayrışabileceğine ve ölçeğin bu şekilde iki boyutlu olarak kullanılabileceğine işaret etmektedir. Carlo ve Randall (2002) tarafindan yapılan sınıflama dikkate alındığında ise ölçeğin içsel (özerk) ve dışsal (kontrollü) motivasyonlu davranışlar temelinde sınıflandırılmasının kısmen sorunlu olduğu görülmüştür. Buna göre, Carlo ve Randall (2002) tarafindan yapılan tanımlama uyarınca içsel motivasyon boyutunda yer alması gereken özgeci olumlu sosyal davranış maddelerinin dışsal motivasyon boyunda yer alması maddelerin katılımcılar tarafindan dışsal motivasyonla harekete gecen davranışlar olarak değerlendirildiğine işaret etmektedir. Bu durum, bir yandan ölçek maddelerinin ters puanlanacak şekilde formüle edilmelerine bağlı olabileceği gibi, söz konusu ölçeğin Türk kültürel bağlamında özgeciliğe karşılık gelmeyebileceğine de bağlı olabilir. Dolayısıyla ilerideki araştırmalarda özgeci olumlu sosyal davranışların Türk kültürü bağlamında işevuruk olarak yeniden tanımlanıp, ters madde kullanmaksızın ölçülmesinde fayda var olacağı düşünülmektedir.

Ayrıca, araştırmada ölçeğin ölçüt geçerliği için kullanılan diğer değişkenlerle olan ilişkilerin yönü değerlendirilirken ilişkilerin korelasyona dayalı olduğuna dikkat edilmelidir. Katılımcıların sadece üniversite öğrencileri olması ölçeğin daha farklı gruplarda test edilmesini elde dilen bulguların geçerliğine katkı sunacaktır.

\section{KAYNAKÇA}

Assor, A., Roth, G., \& Deci, E. L. (2004). The emotional costs of parents' conditional regard: A selfdetermination theory analysis. Journal of Personality, 72, 47-88.

Barber, B. K. (1996). Parental psychological control: Revisiting a neglected construct. Child Development, 67, 3296-3319.

Barber, B. K., Stolz, H. E., \& Olsen, J. A. (2005). Parental support, psychological control, and behavioral control: Assessing relevance across time, culture, and method: V. Assessing relevance across culture: Cross-national replications. Monographs of the Society for Research in Child Development, 70(4), 58-72.

Baumeister, R. F., \& Leary, M. R. (1995). The Need to Belong: Desire for Interpersonal Attachments as a Fundamental Human Motivation. Psychological Bulletin, 117(3), 497-529. 
Bean, R. A., Barber, B. K., \& Crane, D. R. (2006). Parental support, behavioral control, and psychological control among african american youth: The relationships to academic grades, delinquency, and depression. Journal of Family Issues, 27(10), 1335-1355.

Carlo, G., Hausmann, A., Christiansen, S., \& Randall, B.A. (2003). Sociocognitive and behavioral correlates of a measure of prosocial tendencies for adolescents. Journal of Early Adolescence, 23, 107-134.

Carlo, G., \& Randall, B. A. (2001). Are all prosocial behaviors equal? A socioecological developmental conception of prosocial behavior. In F. Columbus (Ed.) Advances in Psychology Research, II, 151-170. New York: Nova Science.

Carlo, G., \& Randall, B. A. (2002). The development of a measure of prosocial behaviors for late adolescents. Journal of Youth and Adolescence, 31, 31-44.

Deci, E. L., \& Ryan, R. M. (1985). Intrinsic motivation and self-determination in human behavior. New York: Plenum.

Deci, E. L., \& Ryan, R. M. (1991). A motivational approach to self: Integration in personality. In R. Dienstbier (Ed.), Nebraska symposium on motivation: 38. Perspectives on motivation, 237-288. Lincoln, NE: University of Nebraska Press.

Deci, E. L., \& Ryan, R. M. (2000). The "what" and "why” of goal pursuits: Human needs and the selfdetermination of behavior. Psychological Inquiry, 11, 227-268.

Deci, E. L., \& Ryan, R. M. (2008a). Facilitating optimal motivation and psychological well-being across life's domains, Canadian Psychology, 49, 14-23.

Deci, E. L., \& Ryan, R. M. (2008b). Self-determination theory: A macro theory of human motivation, development and health. Canadian Psychology, 49, 182-185.

Deci, E. L., \& Ryan, R. M. (2014). Autonomy and need satisfaction in close relationships: Relationships motivation theory. In N. Weinstein (ed.). Human motivation and interpersonal relationships: Theory, research, and applications, 53-73. Dordrecht, Netherlands: Springer.

Deci, E. L., Vallerand, R. J., Pelletier, L. G. \& Ryan, R. M. (1991). Motivation and education: The selfdetermination perspective. Educational Psychologist, 26(3\&4), 325-346.

Eisenberg, N. (1986). Altruistic emotion, cognition and behavior. Hillsdale, NJ: Erlbaum.

Eisenberg, N., \& Fabes, R. A. (1998). Prosocial development. In W. Damon (Series Ed.) \& N. Eisenberg (Vol. Ed.). Handbook of child psychology: 3. Social, emotional, and personality development, 701-778. New York: Wiley.

Eisenberg, N., Wentzel, M., \& Harris, J. D. (1998). The role of emotionality and regulation in empathyrelated responding. School Psychology Review, 27(4), 506-521.

Gagné, M. (2003). The role of autonomy support and autonomy orientation in prosocial behavior engagement. Motivation and Emotion, 27, 199-223.

Grant, A. M. (2008). Does intrinsic motivation fuel the prosocial fire? Motivational synergy in predicting persistence, performance, and productivity. Journal of Applied Psychology, 93, 48-58.

Grant, A. M., \& Berg, J. M. (2010). Prosocial motivation at work: How making a difference makes a difference. Forthcoming in K. Cameron and G. Spreitzer (Eds.). Handbook of Positive Organizational Scholarship. Oxford: Oxford University Press.

Hepach, R., Vaish, A., \& Tomasello, M. (2013). A new look at children's prosocial motivation. Infancy, 18(1), 67-90. 
Jackson, M., \& Tisak, M.S. (2001). Is prosocial behavior a good thing? Developmental changes in children's evaluations of helping, sharing, cooperating and comforting. Journal of Developmental Psychology, 19, 349-367.

Kindap, Y. (2011). A longitudinal study of the relationship between supportive parenting, social adjustment and self-determination level among adolescents on the basis of Self Determination Theory. Unpublished doctoral dissertation, Department of Psychology, Hacettepe University, Ankara.

Kindap-Tepe, Y., \& Aktas, V. (2019). The Mediating Role of Needs Satisfaction for Prosocial Behavior and Autonomy Support. Current Psychology. 10 Haziran 2019 tarihinde https://doi.org/10.1007/s12144-019-00466-9 adresinden erişildi.

Kumru, A., Carlo, G., \& Edwards, C. P. (2004). Olumlu sosyal davranışların ilişkisel, kültürel, bilişsel ve duyuşsal bazı değişkenlerle ilişkisi. Türk Psikoloji Dergisi, 19(54), 109-125.

Roth, G. (2008). Perceived parental conditional regard and autonomy support as predictors of young adults' self-versus other-oriented prosocial tendencies. Journal of Personality, 76(3), 513-534.

Roth, G., Kanat-Maymon, Y., \& Bibi, U. (2011). Prevention of school bullying: The important role of autonomy-supportive teaching and internalization of pro-social values. British Journal of Educational Psychology, 81, 654-666.

Ryan, R. M. (1995). Psychological needs and the facilitation of integrative processes. Journal of Personality, 63, 397-427.

Ryan, R. M. (2009). Self-determination theory and wellbeing. Wellbeing in Developing Countries (WeD). Research Review 1 - June.

Ryan, R. M., \& Connell, J. P. (1989). Perceived locus of causality and internalization: Examining reasons for acting in two domains. Journal of Personality and Social Psychology, 57, 749-761.

Ryan, R. M., \& Deci, E. L. (2000a). Self-determination theory and the facilitation of intrinsic motivation, social development, and well-being. American Psychologist, 55, 68-78.

Ryan, R. M., \& Deci, E. L. (2000b). Intrinsic and extrinsic motivations: Classic definitions and new directions. Contemporary Educational Psychology 25, 54-67.

Ryan, R. M., \& Deci, E. L. (2008). A self-determination approach to psychotherapy: The motivational basis for effective change. Canadian Psychology, 49, 186-193.

Ryan, R. M., Deci, E. L., \& Grolnick, W. S. (1995). Autonomy, relatedness, and the self: Their relation to development and psychopathology. In D. Cicchetti\&D. J. Cohen (Eds.). Developmental psychopathology 1, 618-655. New York: Wiley.

Sayıl, M., \& Kındap, Y. (2010). Ergenin anne babadan algıladığı psikolojik kontrol: Psikolojik kontrol ölçeğinin geçerlik ve güvenirliği. Türk Psikoloji Yazıları, 13(25), 62-71.

Soenens, B., Vansteenkiste, M., Lens, W., Luyckx, K., Goossens, L., Beyers, W, et al. (2007). Conceptualizing parental autonomy support: Adolescent perceptions of promotion of independence versus promotion of volitional functioning. Developmental Psychology, 43, $633-$ 646.

Şimşek, Ö. F., \& Yalınçetin, B. (2010). I feel unique, therefore I am: The development and preliminary validation of the personal sense of uniqueness (PSU) scale. Personality and Individual Differences, 49(6), 576-581.

Tisak, M. S., \& Ford, M. E. (1986). Children's conceptions of interpersonal events. Merrill-Palmer Quarterly, 32, 291-306.

Vallerand, R. J. (1997). Toward a Hierarchical Model of Intrinsic and Extrinsic Motivation. In M. P. Zanna (Ed.). Advances in Experimental Social Psychology, 271-360. New York: Academic Press. 
Warneken, F., \& Tomasello, M. (2008). Extrinsic rewards undermine altruistic tendencies in 20-montholds. Developmental Psychology, 44(6), 1785-1788.

Weinstein, N., \& Ryan, R. M. (2010). When helping helps: Autonomous motivation for prosocial behavior and its influence on well-being for the helper and recipient. Journal of Personality and Social Psychology, 98(2), 222-244. 